\title{
Arkitektur i bøger
}

af Hakon Lund

\section{Den danske Vitruvius}

Arkitekturhistorie i Danmark begynder på Det kongelige Bibliotek. Den 18. oktober 1752 hjemlånte hofbygmester Lauritz de Thurah store dele af en afskrift af Resens Atlas Danicus, så han kunne fortsætte sine bestræbelser på at udgive flere bind af Den danske Vitruvius, hvoraf der allerede var kommet to i henholdsvis 1746 og 1749. Uagtet Resens værk i mange måder er uvurderligt som kilde til vor viden om dele af den ældre danske arkitekturs udseende, takket været bindet med illustrationer til atlasset, må dette dog karakteriseres som et topografisk værk. Hofbygmesteren angav med brugen af den romerske arkitekt Vitruvius' navn, at han lagde vægten på bygningerne. Vitruvius var blevet et pseudonym for arkitektur efter, at man i slutningen af det 15. århundrede for første gang havde udgivet hans lærebog i bygningskunst, en foliant fra 1486. Den fik talrige efterfølgere, og arkitekter kappedes om at illustrere værket udelukkende med teksten som udgangspunkt, idet oprindelige tegninger ikke kendtes. Teksten, som var på latin, kendtes heller ikke i original, men i en afskrifters afskrift cirka syvhundrede år yngre end Vitruvius selv. Ret hurtigt bestræbte man sig på at oversætte bogen til mere alment forståelige tungemål, naturligt nok tidligt til italiensk ved Daniele Barbaro, en veneziansk adelsmand, i 1567. Han havde allerede elleve år tidligere befordret en latinsk udgave i trykken, illustreret af ingen ringere end Andrea Palladio. En tysk oversættelse udkom faktisk før den italienske, allerede i 1548 i Nürnberg ved Walter Rivius, først hundrede år senere kom franskmændene med, endnu senere englænderne.

Disse sidste var de første til at tage Vitruvius' navn forfængeligt i et 
værk om deres egen bygningskunst med Vitruvius Britannicus af Colen Campbell, som udkom mellem 1715 og 1731 i tre bind. Thurah havde som ung været i England og kan ikke have undgået at se værket der, hvorfor det må antages at have været hans umiddelbare inspiration til den danske pendant.

Alle kendte manuskripter fra hofbygmesterens hånd findes i biblioteket, berømtest er vel det tredie bind af Den danske Vitruvius, som forfatteren ikke fik set udgivet. Mens de to første bind nogenlunde holder sig til sagen, arkitekturen, breder uklarheden om formålet sig i det tredie, der antog karakter af et topografisk værk, som må anses for at være indledningen til en serie bind, der skulle slutte med et tiende, hvor det ganske Danmark blev gennemgået. Man kan ærgre sig eller lade være over den manglende udførelse. Ethvert værk vil, hvor vidtløftigt det end er, naturligvis meddele vigtige ting om sin samtid, men hvis Thurah havde haft held, som han havde agt, ville der være blevet endog meget langt mellem de arkitekturhistoriske snapse.

Thurah sigter i sit forord til første bind udtrykkeligt mod udlandet, når han begrunder oversættelserne af teksten til fransk og tysk med, at vi ingenlunde har grund til at skamme os over vore bygninger, der sagtens kan tåle at blive vist frem. Han er således måske den første der vil sætte dansk arkitektur i relation til udlandets, omend han ikke i sin øvrige tekst befatter sig med at drage sammenligninger. Han skildrer sit lands arkitektur, først og fremmest ibilleder, og er sig denne begrænsning bevidst, arkitekturhistoriker er han ikke, men uvurderlig som den der bidrager med kildemateriale.

\section{Udenlandske påvirkninger}

Før Det kgl. Akademi for de skjønne Kunster i 1754 begyndte på at uddanne arkitekter i Danmark, fandtes kun den mulighed, at man benyttede sig af ingeniørkorpsets tilbud, hvilket var det Thurah havde gjort selv. Det er derfor ikke sandsynligt at Det kongelige Biblioteks arkitekturtraktater har haft noget betydning for uddannelsen, hverken før eller siden, men må betragtes som led i kongens egne interesser. Knud Voss har i Partikulærkammerets arkiv undersøgt, hvilke bøger kongehuset købte af den art i 1730erne, og det må anses for sandsynligt, at netop disse er indgået i biblioteket. Ser man på titlerne er det værker som Paul Deckers Architectura Civilis, Johann Bernhard Fischer von Erlachs Entwurf einer historischen 
Architectur, Leonhardt Christoph Stums omfangsrige værker om alle civilarkitekturens aspekter samt Salomon Kleiners pragtværk om prins Eugen af Savoyens Belvedere i Wien Wunderwürdiges Kriegs- und Siegslager ... oder Abbildungen der Hoff-, Lust- und Gartengebäude dess ... Durchl. Fürsten und Herrn Eugenii Francisci Hertzogen zu Savoyen und Piemont ... som udkom $1731 \mathrm{f}$. Disse bøger måtte de unge arkitekter som Thurah og Eigtved rejse til udlandet for at stifte bekendtskab med og deres bygninger i Danmark som Eremitagen, Hirschholm slot og Christiansborg bar tydeligt præg af dette.

Samtidig med Salomon Kleiners forevigelse af Belvedere, et af barokkens hovedværker, indledte en venezianer ved navn Giovanni Battista Piranesi i Rom et livsværk, der skulle blive indledningen til den nyklassicisme, der skulle blive enerådende i næsten et århundrede. I pragtfulde kobberstikværker, til tider af skrækromantisk præg, åbnede Piranesi samtidens øjne for Roms storhed og bearbejdede i sine billeder de antikke ruiner, så deres pragt og udsagn om antikken slog afgørendeigennem. I Alcune Veduti di Archi Trionfali fra 1748 markedsføres interessen for detteevigearkitektoniske motiv, der ikke mindst blev et af nyklassicismens foretrukne motiver. Uagtet deres udprægede pittoreske kvaliteter, fik Piranesis kobberstik overvældende indflydelse på samtidens arkitekter og deres syn på den romerske fortids monumenter. Hans søn Francesco fortsatte faderens bestræbelser, men ofte i mere koldsindige stik, der også redegjorde for fundenes planer og opstalter, som det ses i Teatro di Ercolano, som udkom i Rom i 1783.

En "dansk" udgivelse er i hele sin form direkte afledt af Piranesis værker. Den franske arkitekt Nicolas-Henri Jardin var stipendiat på det franske akademi på corsoen i Rom i 1740erne, netop som venezianeren arbejdede på sine stik af den evige stad. Jardin blevi 1755 kaldt til København for efter Niels Eigtveds død at opføre Marmorkirken, hvoraf kun fundamenterne var lagt. Efter at have gjort adskillige projekter til kirken, blev det sidste endelig approberet af Frederik V. Arkitekten offentliggjorde sine tegninger i Plan coupes et élevations de L'église royale de Fréderic V i en samling kobberstik, hvis teknik tydeligt var afledt af Piranesis. Helt klart står denne afhængighed af det italienske forbillede i to stik i bogen, som ikke har noget med kirken at gøre, men som er eksempler på hvad Jardin foretog sig i Rom. Her er der ikke blot teknisk men også motivmæssig sammenhæng med 


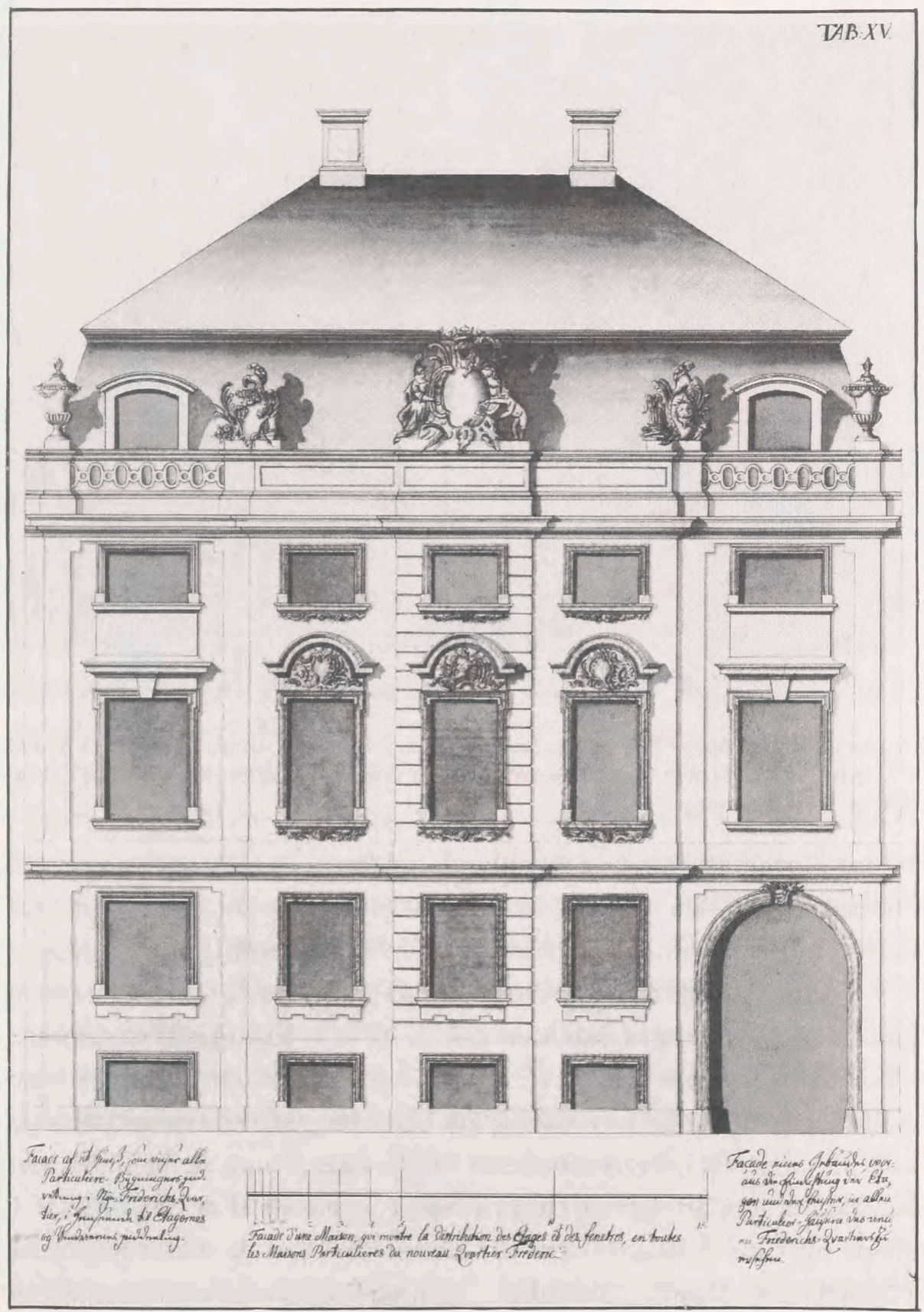

Tab. XV i L. Thura's Den danske Vitruvius, Bd. III. Lauritz de Thurah's eget hus i Amaliegade 25, som stadig findes. Arkitekten har diskret undladt at nævne, at bygningen var opført efter hans egne tegninger eller tilhørte ham. Den håndskrevne tekst lyder: "Facade af et Huus, som viiser alle Particuliere-Bygningers indretning i Nye Friderichs Qvartier, i Henseende til Etagernes og Vinduernes Inddeling." 


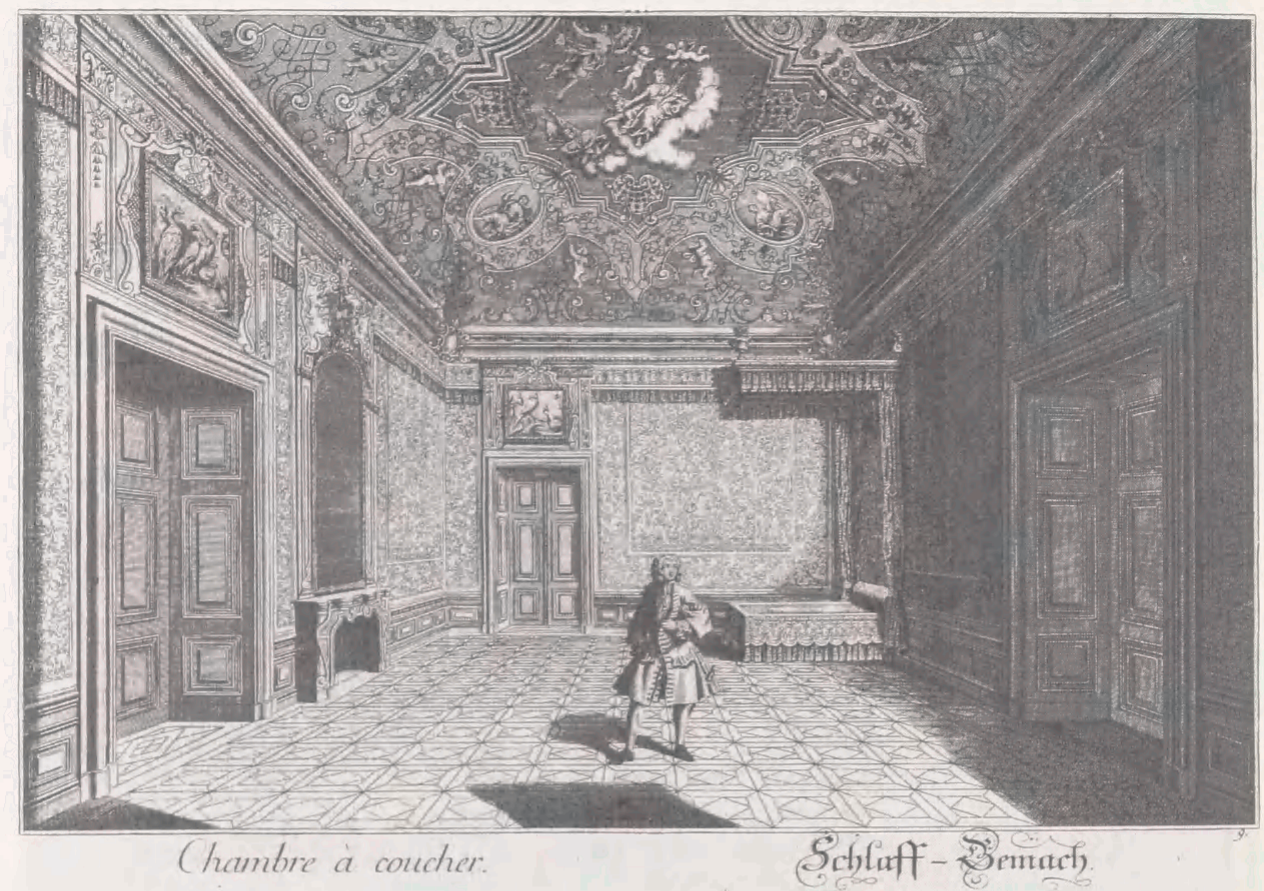

Sovegemak i Det nedre Belvedere, kobberstik i Salomon Kleiners pragtværk Wunder Würdiges Kriegs- und Siegs-Lager, om prins Eugens residens i Wien. Selv var Kleiner ikke arkitekt, men illustrator.

Piranesi i to fantasiprojekter af henholdsvis "Projet d'un Pont Triomphal" og "Chapelle Sépulcrale". I Håndskriftafdelingen findes et rød maroquin indbundet bind, som rummer Jardins originale forlægstegninger for stikværket.

Foruden Thurahs og Jardins håndskrifter rummer samlingen mangt og meget til belysning af dansk arkitektur og dens historie. Thurahs forsøg på en selvbiografi, for eksempel, omend den brat afsluttes med hans besøg på studierejsen ved hoffet i Kassel. Fra Ledreborg stammer en Architectura civilis in einigen Hauptregelen verfasset, et lille attenårhundredes skrift. Mere spektakulær er Christopher Heers samling af planer af de af Christian IV anlagte byer fra Constantinopel til Glückstadt. Også de dansk-hollandske forbindelser fra det syttendeårhundrede kan spores på biblioteket med Evert Janssens tegning i Billedsamlingen til Skanderborg slot. Denne samling rummer vigtige vidnesbyrd om dansk arkitektur og vore forbindelser til udlandet. Frederik V's atlas med sine over 50 folianter er en guldgrube i så henseende. Centralt står bindene om hertugdømmerne og kongeriget; de 
rummer arkitekturtegninger og prospekter fra tiden mellem ca. 1720 og 1760 , der må være blevet samlet ind viden om i arkitekternes beholdninger og kongehusets samlinger. Overlandbygmester Kriegers pyntelige planer fra 1720erne af haverne ved Fredensborg, Frederiksborg og Rosenborg ses her sammen med Nicolas-Henri Jardins udvidelsesforslag til Fredensborg fra 1760.

Tegninger til stottet i Berlin er også blandt bindets klenodier, de blev sendt som gave til Christian VI fra den prøjsiske konge. Slig høflighed skulle gengældes, hvorfor der i generalbygmester Elias David Häussers tegnestue produceredes et flot sæt af tegningerne til Christiansborg. Da prøjserkongen døde forinden afsendelse kunne finde sted, blev tegningerne her i landet, hvor de nu kan ses på Nationalmuseet.

En måske mindre velovervejet kommandoraid mod ingeniørkorpsets arkiver, vist engang i tyverne, skaffede biblioteket en stor samling tegninger til fæstninger og militære bygninger i tidligere danske besiddelser som hertugdømmerne og de vestindiske øer mv. De fjæler sig nu lidt fremmedartede blandt de mange civile anlæg, som et eksempel på tyvernes mærkværdige trang til uhistorisk fremfærd, når det gjaldt om at skaffe sig materiale på andre samlingers bekostning.

I 1830erne var det forresten gået den anden vej, da Just Matthias Thiele behjertet begyndte at udskille de blade, som til sidst skulle blive til den kobberstiksamling, som biblioteket måtte afgive til Kunstmuseet. Her var der selvfølgelig ikke tale om arkitektur, men først og fremmest om billedkunst. Dog blev en for dansk arkitekturhistorie vigtig samling ladt tilbage i Billedsamlingen, nemlig Müllers Pinakotek, måske den kvalitetsmæssigt fornemste samling danske kobberstik fra det attende århundrede. Forsåvidt er det en samling til landets historie i bred forstand, men med de mange arkitektoniske og topografiske stik har den været meget søgt af arkitekturhistorikere.

\section{Havekunst}

Selv om beklageligt mange af bibliotekets fine bøger om havekunst er blevet deponeret på Danmarks Veterinær- og Jordbrugsbibliotek, er der dog værdifulde folianter tilbage. Fra 1647 stammer Hans Razmussøn Blocks Horticultura Danica, måske det vigtigste kildeskrift til tidlig dansk havekunst, der sikkert skylder et billedværk som Johannes Vredeman de Vries Hortorum 
vidiariorumque ... (1583) ikke så lidt, om ikke netop ved sit beskedne udseende, så dog gennem indholdet. En anden dansk-udenlandsk parallel kan spores i en vis sammmenhæng mellem Ideenmagazin für Liebhaber von Gärten Englischen Anlagen ... , en serie påbegyndt i 1799, og vor egen slotsgartner Johan Ludvig Mansas Udkast til Hauge-Anlæg i den engelske Smag ... , som ovenikøbet udkom året før det tyske magasin. Mansas tynde bog, som for tiden noteres til skyhøje priser i engelske antikvarkataloger, rummer sart farvelagte stik af en række ideale eksempler på haveanlæg.

\section{Arkitekturtraktater og lærebøger}

Fra det attende århundredes midte og fremefter begynder der at vise sig talrige arkitekturtraktater og lærebøger, der af ydre på ingen måde kan kappes med de ældre, royale bind. De har titler, der fortæller hvorfor de er beskedne: Encyklopädie der bürgerlichen Baukunst eller Anweisung zur Bürgerlichen Baukunst eller Traité d'architecture pratique, simple lærebøger til brug ved undervisning.

I 1820ernes begyndelse startede overbygningsdirektør C.F. Hansen udgivelsen af egne værker i kobberstik. Det skete i hefter, som med mellemrum bragte et antal planer, snit og facader foruden perspektiver og detaljer af Christiansborg, Råd-og domhuset på Nytorv og Vor Frue kirke, men også gengivelser af hans bygninger for private i Altona og Holsten. Allerede C.F. Harsdorff fik lavet nogle stik som forberedelse til en sådan bog, men det blev ved forsøget. I udlandet havde især englændere som W. Thomas, William Chamers og John Soane forlængst givet bolden op, men også i Tyskland havde Karl Friedrich Schinkel påbegyndt udgivelsen af egne værker omtrent samtidig med Hansen.

Tilstudiet af arkitekturi videre omfang findes iblandt Billedsamlingens ældre fotografier, især fra den nære Orient og Ægypten, optagelser af stor sjældenhed og med den skønhed, der følger af, at fotografen tog sin tid, påtvunget af apparaturets omstændelighed og primitivitet.

Uagtet at tidernes skiften forlængst har medført, at litteratur og materialer til studiet af arkitekturen nu anskaffes andre steder, vil Det kongelige Biblioteks samlinger bestandig være uundværlige til samme formål. 